\title{
A PEDIGREE OF MICROPHTHALMIA WITH MYOPIA AND CORECTOPIA
}

BY

C. H. USHER

ABERDEEN.

NOT very many pedigrees of microphthalmia have been published, - and a number of these refer only to cases in a single sibship or else to a parent and child. In the list of literature appended to this paper, there are five pedigrees, however, that show continuous descent in three generations (Page, Mayerhausen, Martin, Schaumberg, Ravá), one pedigree that shows discontinuous descent with affected members in three generations (Barkan), and another both continuous and discontinuous inheritance with affected members in three generations (Cunier), but it does not appear from the descriptions of the cases that any of the microphthalmic individuals in these, or any of the pedigrees were myopic. Furthermore, the inheritance of microphthalmia with corectopia is apparently uncommon. Harman recorded a pedigree where a man, with two of his daughters, and his half sister had microphthalmic eyes and corectopia, but this is the only instance known to me. The refraction of the eyes in his cases is not mentioned. Krükow recorded the cases of two microphthalmic brothers, one of whom had corectopia in his left eye. Ischreyt mentioned microphthalmia in a mother and daughter. The position of the pupils of the 
former were eccentric upwards and inwards, that of the latter was not stated. von Ammon*, in 1841, published the cases of two microphthalmic brothers, one of whom had eccentric pupils upwards and inwards and the other centrally placed pupils. $\mathrm{He}$ also described and figured several isolated cases of microphthalmia with corectopia. Best, ${ }^{11}$ more than fifty years later, in referring to von Ammon's view that the association of microphthalmia and corectopia. was exceedingly frequent, stated that later authors almost never observed it, but, on the other hand, that a characteristic form of corectopia was associated with ectopia of the lens and tremulous iris. Such cases are often myopic and constitute Best's third group. His second group consists of corectopia with some common developmental anomalies of the eye, such as buphthalmia and microphthalmia.

The pedigree which forms the subject of this paper shows direct descent of microphthalmia with corectopia and myopia from a male proved to have had myopia and reported by two of his sons and a grand-daughter, all of whom were microphthalmic, to have had small eyes like their own. All of these abnormalities were present in each affected individual and appear in probably four consecutive generations, and certainly in three. The microphthalmia and corectopia invariably affected both eyes, and the pupils were markedly displaced upwards and inwards in each case, excepting possibly one in which they were described as being "eccentric towards nasal side." From a perusal of their notes, it is evident that the microphthalmic cases present several of the characters that occur in Best's third group of corectopia, but, the presence of microphthalmia would assign them a place rather in his second group.

There was no coloboma of lens, iris, choroid, optic nerve, or eyelid in any case, but the presence of an eccentric pupil upwards and inwards was invariable, and in some cases the anterior surface of the iris presented peculiarities. In one case (III. 22) the circulus iridis minor was absent at the inner upper part in the right eye, and at the outer part in the left eye. In another (III. 24) the circulus iridis minor was complete in the left eye, but absent at the nasal side in the right eye. A mother (III. 8) and her two daughters (IV. 6 and 7), had irides of unusual appearance. The peripheral zone, smaller than the pupillary zone, was of a darker grey colour than the pale grey of the larger pupillary zone which ended in a ragged edge where it met the darker area.

The measurements of the transverse diameters of the corneae were from eight to ten millimetres. The lens was generally clear, though there were some exceptions. In a man, aged 68 , there were

* Vide Gescheit. ${ }^{4}$ 
Pedigree of Microphthalmia and Myopia

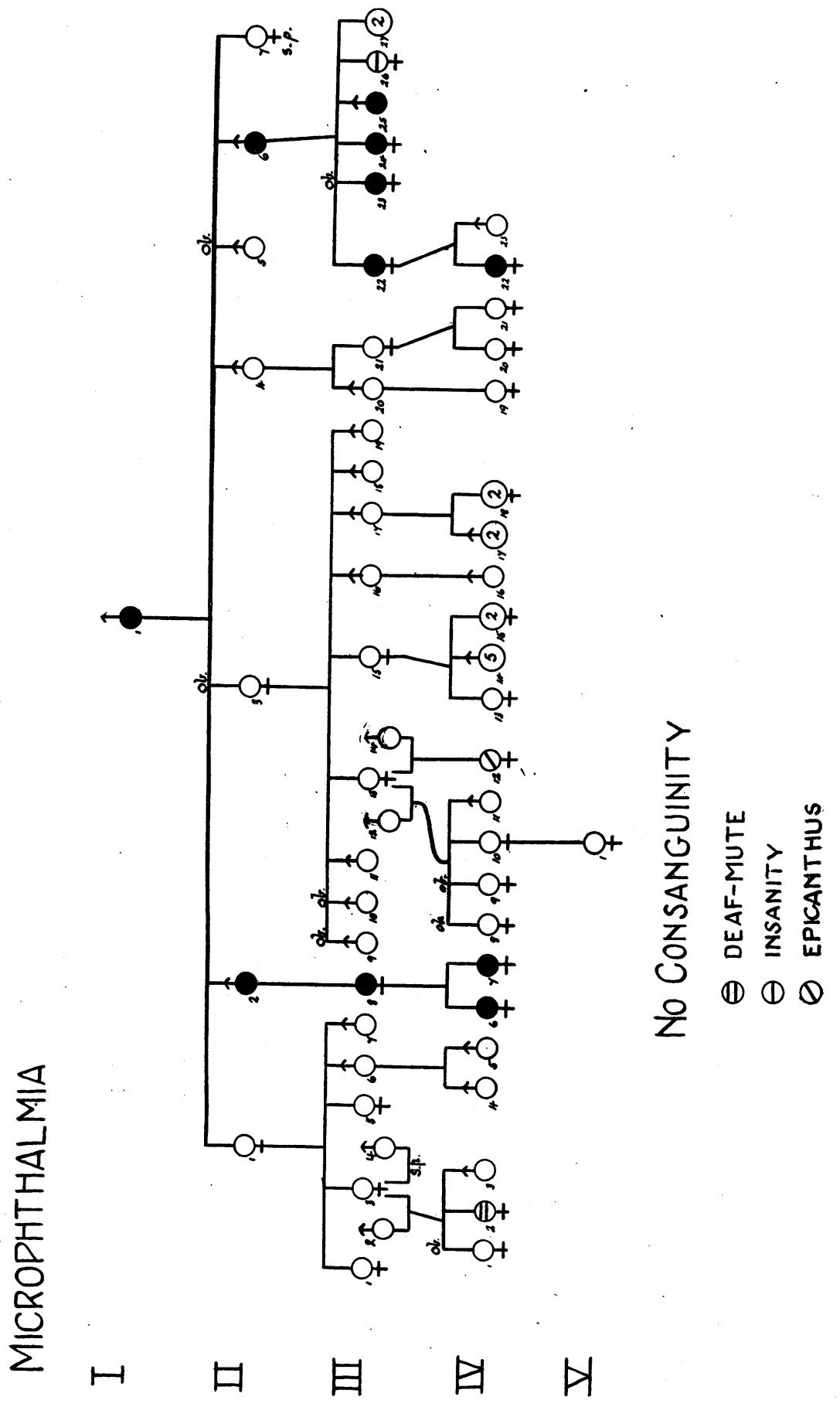


cortical striae and posterior polar cataract, a woman, aged 41, had an opaque dislocated lens, and another woman a secondary cataract; in two cases peripheral dot opacities were present. Glaucoma occurred in two of the cases. Nystagmus was noted in five of the cases, and its absence-in two. There were no deformities of other parts of the body, and none of the cases was mentally affected.

The myopia in these cases is of considerable interest. Most cases of microphthalmia are hypermetropic, and in some the hypermetropia is of high degree, as in Roll's ${ }^{1}$ case, where there were twenty dioptres, yet some cases with myopia have been recorded, such as Brailey's case with twelve dioptres in the right eye, Nieden's ${ }^{3}$ case which was highly myopic, and Pyle's ${ }^{4}$ case with twenty dioptres. In the pedigree under consideration myopia was present in all the microphthalmics, though in two cases, one a child of three years of age, one eye only was myopic, and from a study of the literature of microphthalmia the question arose whether the myopia was of the usual form-axial, or had it some other origin situated in the lens or cornea? Becker ${ }^{5}$ attributed the presence of myopia in a microphthalmic boy of fifteen years, to the very short radius of curvature of the small cornea and regarded it as a curvature myopia. In some of the microphthalmic cases in the pedigree under consideration the cornea appeared to be flatter than usual, yet in two cases where the radius of curvature of the anterior surface was measured by the ophthalmometer it was found to be rather less than the $7.8 \mathrm{~mm}$. and $7.7 \mathrm{~mm}$. given by Donders ${ }^{6}$ as the average in man and woman respectively, but not sufficient to account for the degrees of myopia that were present. Mayou ${ }^{7}$ examined an enucleated microphthalmic eye of a six months old child and found a lenticonus posterior. In view of Mayou's case the possibility was considered whether the explanation of the myopia in the pedigree now reported might not be found in an hereditary malformation of the lens, but in none of the cases examined for this condition was there any evidence of lenticonus posterior. There is reason to believe that the myopia was produced by elongation of the posterior part of the eyeball, for the usual fundus changes found in ordinary cases of myopia were present in several of the cases, and in at least two cases, seen at intervals, a marked increase in the degree of myopia occurred. Querenghi ${ }^{8}$ saw in the fundus of a microphthalmic eye that had six dioptres of hypermetropia, appearances that had all the characters of a progressive posterior staphyloma. The association of corectopia with microphthalmia is in a sense contradictory in reference to the state of the refraction, for in microphthalmia the refraction is usually hypermetropic, whilst in corectopia with ectopia of the lens it is often myopic, and there is some evidence of ectopia of the lens in several 
of the cases in this pedigree. Iridodonesis was present in four of the cases, the edge of the lens was visible in the pupil of one of them, an opaque lens showed partial dislocation in another, and the anterior chambers were each of unequal depth in a fifth case (III, 24). In all of the cases vision was poor even after correction of the error of refraction. The lowest degree of myopia present was $1 \mathrm{D}$., found in a girl, seven years of age, but it had increased to $7 \mathrm{D}$., by the time she was fourteen. The highest degree of myopia was $20 \mathrm{D}$. The combination of albinism* and microphthalmia, as seen in the child IV. 7, has been recorded by Posey ${ }^{9}$ in a four year old female child. Of other members of the pedigree without microphthalmia II. 1 , and her son III. 7, were highly myopic. IV. 2, is a deaf-mute, and III. 26, one of a microphthalmic sibship, was mentally affected and died in a lunatic asylum.

The following is an account of the individual cases of microphthalmos and of some other cases in the pedigree :-

I 1. G. W.—, male, had small eyes. This is vouched for by his son II 2, who said he was sure that his father had small eyes, and also by his son II 6 , and by his grand-daughter III 8 . In a register book at the Aberdeen Royal Infirmary his name was entered on June $2.3,1890$, and his age given as 68 . In the column for diagnosis, instead of the name of some disease as in other cases, was inserted "myopia, choroidal atrophy, tremulous iris, striae and posterior polar cataract, large staphyloma posticum." The cornea was not mentioned. He was illegitimate. In 1897 one of his sons reported that he (I 1) had been blind for five years.

II 2. G. W'.—, male, age 49 (1895), always near sighted, complained that the vision of his right eye had been failing for one week, and that everything appeared green to that eye. The squint of his right eye-internal concomitant-was of long standing. Corneae are small, transverse diameters $=9.5 \mathrm{~mm}$. Refraction: myopia, R. more than 11 D., V. not improved beyond 3/36; L. $20 \mathrm{D}$. in vertical meridian and $25 \mathrm{D}$. in horizontal meridian, V. with correction $=6 / 60$; pupils eccentric towards nasal side, iridodonesis; posterior staphyloma with choroidal atrophy surrounding O.D. in each eye, in $L$. extensive choroidal changes at macula, no vitreous opacities. When seen again 1904 : R.V.= hand movements, faulty projection, T+1, A.C. shallow, P. oval, sluggish to light. L.T. $\mathrm{n}$; O. D. $\mathrm{n}$; neither eye moves fully outwards. In $1911:$ R. T. +3 , very shallow A.C.; L.A.C. deep, $P$. contracts readily to light, upper margin of lens visible in upper part of $P$., lens becoming opaque, $V=$ counts fingers at 1 foot. In

\footnotetext{
* Schultze ${ }^{10}$ found in the larvae of the salamander albinism associated with microphthalmia, and he refers to the presence of albinism with microphthalmia in the normal proteus anguinus.
} 
1920 : no p.l. in either eye, no nystagmus, much corneal opacity, R. T. n., L. T. +2 .

II. 6. J. W-, male, age 41 (1897), complained of inflammation of his right eye off and on for one year. The sight of this eye failed all of a sudden in boyhood. Corneae small, transverse diameter $=10 \mathrm{~mm} ., \mathrm{R} . \mathrm{V} .=$ no p.l., cornea nebulous all over $; \mathrm{L}$. myopia $20 \mathrm{D}$., $\mathrm{V}$. with correction $=3 / 60$, is wearing $-12 \mathrm{D}$. and $-16 \mathrm{D}$. lenses reversible. Ps. ectopic far upwards and inwards, iridodonesis; no details of right fundus. L. myopic crescent ; R.T.+1, L.T.n., left lens hazy.

III. 8. Mrs. A. W-—, age 21 (1896), was always near sighted and had never worn glasses. Corneae small and clear, no evidence of conical cornea. Refraction : R, myopia $11 \mathrm{D}$. in vertical meridian and $13 \mathrm{D}$. in horizontal meridian, V. with correction $=6 / 36$ not fully; L, myopia $14 \mathrm{D}$. in vertical meridian and $9 \mathrm{D}$ in horizontal meridian, V. with correction $=6 / 24$ not fully ; large white myopic crescent in each. Seen again in 1907, "sight getting worse." R.V. <6/60; L.V. $6 / 60$ with correction. In 1920 : R.V. with $-11 \mathrm{D}=2 / 60$; L.V. with $-11 \mathrm{D}=2 / 60$; corneal transverse diameter $=9$ or $9.5 \mathrm{~mm}$. in each, corneal curvature : the ophthalmometer shows in R. that radius of cornea is $7.6 \mathrm{~mm}$.; in L. $7.3 \mathrm{~mm}$.; sclero-corneal junction is well defined; Ps, ectopic up and in, are not quite circular; no nystagmus; no iridodonesis, surface of iris pale grey with a much darker peripheral zone, a well defined irregular line where the two zones meet; lenses clear with exception of a few small dots below, no evidence of lenticonus posterior; optic discs normal with large area of choroidal atrophy surrounding them, and patches of complete and partial choroidal atrophy; some vitreous opacity; T.n. A.Cs. not very shallow; eye movements full ; lacrymal apparatus normal; palpebral fissures measure $27 \mathrm{~mm}$. in length. When the upper lid is raised and she looks downwards the eyeball appears to be of a fairly large size, and similarly on drawing the lower lid down when she looks upwards.

III 22. Mrs. M.— a a 41 (1921), a delicate woman, formerly had stomach trouble for some years, pain after food, sometimes vomiting, and occasionally haematemesis. Had gastro-enterostomy performed last year for dilated stomach ; corneal transverse diameter in each eye is $9 \mathrm{~mm}$.; the ophthalmometer shows a corneal radius of $7.5 \mathrm{~mm}$. in the horizontal meridian, corneal edge is well defined though less sharply than in a normal eye; the eyeballs are smaller than normal eyes; eyelids, eyelashes, and puncta lacrymalia are of normal appearance; eyelids not sunken back into orbit, palpebral fissures measure $24 \mathrm{~mm}$. in length and $6 \mathrm{~mm}$. at widest part ; constant rotatory nystagmus; R.V. with -12 D. sph. $=2 / 60$, but she prefers $a-20 \mathrm{D}$. sph., reads $1 \mathrm{~J}$. at about $2^{\prime \prime}$; L.V.= no p.l., Ps. equal; R.P. contracts to light, but not consensually; 
L.P. no contraction to light, but contracts consensually; irides bluish with much yellow in stroma; in R., corona is absent above, and in L., at outer part ; left iris is tremulous, not the right iris; Ps. remarkably eccentric, both are displaced upwards and inwards, right $P$. is black, left $P$. is grey owing to an opaque lens, which is partially dislocated into the 'vitreous; right lens, clear, shows no evidence of lenticonus posterior; oph : R. no vitreous opacities, or evidence of hyaloid artery detected; a large white area of complete choroidal atrophy surrounding O.D. extends well outwards into macula, no coloboma of choroid; $L$, no red reflex; T.n. in each eye. Her vision has dețeriorated, for in 1907 her notes indicate that R.V. with $-16 \mathrm{D}$. sph. $=6 / 24$; L.V. = p.l., is myopic, degree not determined ; corneae, transverse diameter from 8.5 to $9 \mathrm{~mm}$. ; fundus changes were present in L. as well as in R.

III 23. L.W., female, age 13 (1893), for three years was an inmate of an asylum for the blind, where she was admitted in 1893. On her admission form, under the late Sir James McKenzie Davidson's initials, occurs the following: "High myopia. L. secondary cataract." Her sister (III. 22) says she had small eyes like her own, and Mrs. W.-(III. 8), her cousin, indicated that she had small eyes and nystagmus. She was blind for some years before she died, unmarried, aged 31 .

III. 24. Mrs. McP —, age 21 (1903), complained of frontal headache, which was worse when reading. Corneal transverse diameters $=10 \mathrm{~mm}$. ; L. corneal nebula. Refraction: R.Hm. 5 D. in vertical meridian and $5.75 \mathrm{D}$. in opposite meridian, V. with correction $=6 / 12$ not fully; L. My. 7 D., V. with correction=3/60; Ps, nearly circular, contract readily to light, ectopic up and in, nasal margin of R.P. is little more than $1 \mathrm{~mm}$. from corneal margin; no iridodonesis; rotatory nystagmus; surface of iris in R. has an incomplete corona at nasal side; there the iris is slate colour and looks thinned, in L. the corona is complete; lenses have peripheral dot opacities; fundi normal ; no coloboma of choroid or iris ; T.n. ; R. pupillary membrane across lower part of $\mathrm{P}$. and fine pigmented dots on lens capsule. She has lupus of face. Seen again in 1907 and 1912; marked convergent concomitant strabismus of L; A.C.s deep down and out, shallow up and in; no ptosis.

III. 25. J. W.-, male, age 12 (1897), was always short sighted. Corneal transverse diameter $=8 \mathrm{~mm}$. in each eye. Refraction: R. myopia $7 \mathrm{D}$. in oblique meridian, and $10 \mathrm{D}$. in opposite meridian, V. with correction $=2 / 60 ;$ L. myopia $7 \mathrm{D}$. in oblique meridian, and $10 \mathrm{D}$. in opposite meridian, $\mathrm{V}$. with correction $=5 / 60$; Ps. markedly ectopic up and in, contract to light and on accommodation, approach closely to corneal margin, and are not circular; lateral nystagmus. Oph.: large crescent of complete choroidal atrophy at outer margin of each O.D., and in R. another 
patch with well defined margin; at macula; in L. an opacity in front part of vitreous; ptosis, partial, about 1/3. Teeth good; arch of palate rather high.

IV. 6. A. W. - female, age 2 (1907), holds things too near. Corneal diameter $=9.5 \mathrm{~mm}$. in transverse direction in each. Refraction: R. myopia 3.5 D. in horizontal meridian, and 4.5 D. in vertical meridian; L. myopia $1.50 \mathrm{D}$. in horizontal meridian, and $2.50 \mathrm{D}$. in vertical meridian; Ps. markedly ectopic upwards and inwards; rotatory nystagmus. The myopia had increased to $10 \mathrm{D}$. in each eye by the age of 7. Seen again in 1920 : corneae are clear with well defined margins, curvatures of anterior surfaces look less convex than usual, giving an impression of flatness; iris surface has a dark grey peripheral zone with irregular margin where it joins a larger pale grey pupillary zone containing some yellow spots; no lens opacity, no lenticonus posterior; fundi moderately pale, posterior staphyloma of complete choroidal atrophy in each; eyeballs look small in profile, but appear to be of larger size when exposed by raising upper or depressing lower lid, when the eye is looking down and up respectively. A.C. not shallow, and is of uniform depth; no iridodonesis, slow rotatory nystagmus; lids normal; all puncta lacrymalia are present; length of palpebral fissure is $24 \mathrm{~mm}$. She was born at full time; began to menstruate at age of 12 .

IV. 7. E. W.—, female, age 6 (1912), corneae small. Refraction : given as, R. My. 1 D. in vertical meridan and Hm. 1 D. in horizontal meridian; L. My. $1.5 \mathrm{D}$. in vertical meridian and emm. in horizontal meridian; L. diverges; rotatory nystagmus; fundi typically albinotic and hair is very fair; she is a fairly complete albino. Seen again in 1920, myopia had increased in $\mathrm{R}$. to $7 \mathrm{D}$. in horizontal meridian and $8 \mathrm{D}$. in vertical meridian, V. with correction $=6 / 36$ and in L. to $7 \mathrm{D}$. in horizontal meridian and $8 \mathrm{D}$ in vertical meridian, $\mathrm{V}$. with correction $=6 / 36$; corneal transverse diameters $=10 \mathrm{~mm}$., corneae are clear, edges well defined and curvature less marked than normally; Ps. markedly ectopic upwards and inwards, not quite circular, lenses clear, no lenticonus posterior, no iridodonesis, iris bluish grey with darker peripheral zone which has a sharply defined irregular edge where it joins the larger and much paler pupillary zone: A.C.s of moderate and even depth ; posterior staphyloma in each, not noted eight years ago ; eyeballs generally give an impression of smallness; constant fine rotatory nystagmus. Mother says she was prematurely born, but adds that her doctor said she was born at full time; menstruation has not yet commenced.

IV. 22. I. M-; female, age 3 (1921), born at full time; corneae small and transparent, edges well defined, no conicity, indeed they have rather a flattened appearance, transverse diameter 
of each measures $9 \mathrm{~mm}$., whole eyeball is too small ; no nystagmus; palpebral fissure quite wide, eyelids with puncta and eyelashes have a normal appearance; irides blue, with some yellow in stroma; no iridodonesis; lenses clear, no lenticonus posterior; A.C.s of equal and usual depth; oph.: optic discs normal, fundi pale. Refraction : in R. shadow's are hypermetropic, in L. myopic; holds objects close to her; Ps, black, contract to light, are markedly ectopic upwards and inwards, and are ovoid.

The next two cases, with high myopia, were examined without the knowledge that they were members of this pedigres. As there is no mention in their notes of the size of the cornea, it is unlikely that there was, at any rate, a noticeable degree of microcornea in either of them, and as both went abroad they could not be re-examined. The first case, II 1, age 65 (1914), was always near sighted. With her right eye she read letters of $20 \mathrm{~J}$; there was high myopia, diffuse lens opacity, and normal tension; left eye had perception of light, iridodonesis, a lens dislocated into lower part of vitreous chamber, a large posterior staphyloma of complete choroidal atrophy, much retinal pigmentation at periphery of fundus, with tension +1 ; optic disc of good colour and not cupped. Her son, III 7, age 24 (1910), had in his right eye myopia 22 D., V. with correction $=6 / 36$; in the left eye myopia $18 \mathrm{D}$., V. with correction $=6 / 18$; in each fundus were extensive myopic changes.II 5 , died in childhood, III 9, and 10, killed in the war. III 11, newly married. III 18 , and 19 , unmarried. III 27 , two miscarriages. III 20, wrote that he and his daughter, IV 19, had perfectly sound eyes and that they had had no trouble with their sight. IV 20, and 21, in South Africa, both see well. IV 1 , died aged three.

\section{A LIST OF PUBLICATIONS THAT SHOW INHERITANCE OF MICROPHTHALMIA}

1. Pönitz.--Zeitschr. für Natur und Heilk., herausgegeben von den Professuren der chir. med. Academie zu Dresden. Dresden, 1822, Vol. VIII, Part ii, p. 60 (Ref. Gescheit, v. Ammon's Zeitschr.für die Ofhthal., Vol.II, p. 257, Dresden, 1832).

2. Fischer, C. E. $-Z$ weier an Microphthalmus leidender Geschwister. Auszüge aus den Jahrbüchern der Krankheiten Lüneburgs, S. Hufeland's Jl. der pract. Heilk. . Supplem. Heft. des Jahrg. 1827, p. 27. (Ref. Gescheit, Ant.) Zeitschr. für die Ophthal., Vol. II, p. 257, Dresden, 1832).

3. Wutzer.-In Meckel's Arch. f. Anat. u. Physiologie, 1830, Parts 2. 3, p. 179). Quoted by Karl Himly in his "Die Krankheiten und Missbildungen des menschlichen Auges," Part i, p. 528. Berlin, 1843, and by Gescheit, Ant. Zeitschr. für die Ophthal., Vol. II, p. 257, Dresden, 1832.

4. Gescheit, Ant. - "Ueber Microphthalmos oder der angeborene Kleinheit der Augen." v. Ammon's Zeitschr. für die Ophthal., Vol II, p. 257, Dresden. 1832. (The two microphthalmic brothers mentioned by v. Ammon, F.A., in " Klinische Darstellungen der Krankheiten des Menschlichen Auges," Part iii, Table iii, Figs. 1 and 3, Berlin, 1841, are the same individuals as those described by Gescheit).

5. Himly, K.- "Die Krankheiten und Missbildungen des menschlichen Auges," Part i, p. 530, Berlin, 1843. 
6. Stoeber.-Gazette med. de Strasbourg. Quoted by De Beck, ref. Loeb, Clarence. "Hereditary Blindness and its Prevention," Ann. of Ophthal. No. 2, p. 245, Vol. XVIII, 1909, also, by Cunier, Ann. d'Oculistique, Vol. XIII, p. 33, Bruxelles, 1845.

7. Cunier,M.F.- "Microphtalmie et surdi-mutité héréditaires," Ann.d'Oculistique, Vol. XIII, p. 30, Bruxelles, 1845. (2 pedigrees).

8. White Cooper.-“" Microphthalmos." R.L O.H. Reports, Vol. I, p. 110, 1858.

9. Harlan, Geo. C. - " Report of an examination of the eyes of 167 inmates of the Pennsylvania Institution for the Instruction of the Blind." Amer. Jl. of the Med. Sciences, Vol. LXV, p. 410, 1873.

10. Page, H. "Transmission through three generations of microphthalmos, irideremia and nystagmus." Lancet, p. 193, August 8, 1874.

11. Krükow. - "Zwei Fälle von angeborenem Hornhautstaphylom," Arch. für Ophthal., Vol. XXI, Part ii, p. 213, Berlin, 1875.

12. Benson, A. H. - "Congenital irideremia of both eyes." Brit. Med. Jl., Vol. II, p. $359,1878$.

13. Ravá, H. - "Estrazione doppia di cataratta felicemente esequita." Annali di Ottalm, Vol. IX, Parts iii and iv, p. 281, ref. Nagel's Jahresbericht, p. 387, 1880.

14. Manz, W. - “Z Zwei Fälle von Mikrophthalmus congenitus nebst Bemerkungen über die zystoide Degenerationen des fötalen Bulbus." Arch.f. Ophthal. Vol. XXVI, p. 154, Berlin, 1880.

15. Schaumberg, C. F.- "Casuistische Beiträge zu den Missbildungen des Auges." Inaug. Dissert. Marburg, 1882, ref. Nagel's Jahresbericht, p. 257, 1882.

16 Mayerhausen. G. "Directe Vererbung von beiderseitigem Microphthalmus." Centralbl. f prakt. Augenheilk., p. 97, 1882.

17. Schenkl. - "Jahresbericht der deutschen Poliklinik in Prag," ref. Nagel's Jahresbericht, p. 281, 1884.

18. Appenzeller.- "Beitrag zur Lehre von der Erblichkeit des grauen Stars." Mitteil. d. ophth. Klinik in Tübingen, Vol. II, Part i, p. 120, ref. Nagel's Jahresbericht, p. 297, 1884.

19. Phïger, E.- "Microcephalie und Microphthalmic." Arch. für Augenheilk., Vol. XIV, p. 1, Wiesbaden, 1885.

20. Magnus, H. -Die Jugend-Blindheit, p. 36, Wiesbaden, 1886.

21. Martin, F. - "Ueber Microphthalmus." Inaug. Dissert. Erlangen, 1888, ref. Nagel's Jahresbericht, p. 227, 1888.

22. Smith, Priestley.- "On an instance of Hereditary Glaucoma and its cause." Ophthalmic Review. Vol. XIII, p. 215, 1894.

23. Hirschberg, J. - "Angeborener grauer Star als Familienübel," Ceniralbl.f. prakt. Augenheilk., p. 271, 1897.

24. Reber, M.- "Mikrophtalmie compliquée d'hypermetropie excessive et d'anomalies de la macula, observé chez trois sœurs." Ann. d'Oculistique, Vol. CXIX, p. 445, 1898.

25. Bruns, Henry Dickson.-_ “A Microphthalmic Family.” Amer.Jl.of Ophthal., Vol. XVI, pp. 68-70, 1899.

26. Scherenberg, K.- "Beiträge zur Lehre vom reinen Mikrophthalmus." Inaug. Dissert Tübingen. 1900, ref. Nagel's Jahresbericht, p. 297, 1900.

27. Lavagna, J.- "Contribution à la tératologie et à l'embryologie oculaire.' (Société méd. de Monaco, 17 avril, 1901). Nice: "Petit Niçois," ref. Nagel's Jahresbericht, p. 270, 1901.

28. Barkan, A - "Congenital arrested development in the fundus of each eye." (San Francisco Society of Eye, Ear, Nose and Throat Surgeons.) Ophthal Record, Vol. X, p. 216, 1901.

29. Argyll Robertson. - Discussion, Ophth. Society, on Bronner's paper on Microphthalmos. Trans. Ophthal. Soc., Vol. XXII, p. 211, 1902.

30. Fuchs, E. - Discussion, Ophthal. Society, on Bronner's paper on Microphthalmos. Trans. Ophthal. Soc, Vol. XXII, p. 212, 1902.

31. Bronner, Adolph. - " Notes on two families with bilateral congenital microphthalmos and cataract." Trans. Ophthal. Soc., Vol. XXII, p. 209, 1902. (2 pedigrees).

32. Osterroht, Dr.- " Ein Fall von hochgradiger Hypermetropie bei angeborenem Mikrophthalmus mit inneren Komplikationen." Beiträge zur Augenheilk., Deutschmann, Vol. VI, 60, p. 33-41, 1904. 
33. Sulzer, M.-“ Microphtalmie unilatérale droite." Recueil d'Ophtalmologie, p. 356, 1906.

34. Harman, N. Bishop. - " New pedigrees of cataract-posterior polar, anterior polar and microphthalmia, and lamellar." Trans. Ophth. Soc., Vol. XXIX, p. $296,1909$.

35. Harman, N. Bishop.-" Ten pedigrees of congenital and infantile cataract; lamellar, coralliform, discoid, and posterior polar with microphthalmia." Trans. Ophth. Soc., Vol. XXX, p. 251, 1910.

36. Stuelp, O. - "Ueber familiären Mikrophthalmus congenitus bei 8 von 14 Geschwistern." Arch.f. Ophthal., Vol. LXXXVI, p. 136, 1913.

37. Thomsen, Chr.-_ "Ueber die Vererbung des Mikrophthalmus mit und ohne Katarakt." Inaugural - Dissertation. Rostock, 1913.

38. Ischreyt, G. - "Zur Kasuistik der Missbildungen des Auges. Mikrophthalmus." Klin. Monatsbl. f. Augenheilk., Vol. LVII, July-December, p. 504, 1916.

39. Ring, G. O.- " Concerning coloboma of the iris in association with congenital cataract." Ophthalmic Record, March, 1917, ref. Arch. of Ophthalm., Vol. XLVI, p. 392, 1917.

ADDITIONAL LITERATURE REFERRED TO.

1. Roll, G. W.-_" Microphthalmos." Trans. Ophthal. Soc., Vol. XXIII, p. 398, 1903, and Ophthalmic Review, p. 177, 1903.

2. Brailey, W. A.- "Double Microphthalmos with defective development of iris, teeth and anus. Glaucoma at an early age.". Trans. Ophthal. Soc., Vol. X, p. 139, 1890.

3. Nieden, A. - "Vier Fälle von Coloboma vag. nervi optici ohne weitere Spaltbildung." Arch.f. Augenheilk., Vol. VIII, p. 22

4. Pyle.- " Microphthalmos, extensive colobomata and other congenital defects." Ophthal. Record, p. 211, 1908.

5. Becker, F.- "Microphthalmos." (Verein d. Aerzte Dusseldorf's). Deutsche med. Wochenschr., p. 485 (Nagel's Jahresb., 1907).

6. Donders, F. C.- "Accommodation and Refraction of the Eye." The New Sydenham Society, London, Vol. XXII, p. 89, 1864.

7. Mayou, S. - " Microphthalmos resembling glioma with lenticonus and hypertrophy of the ciliary body." Trans. Ophthal. Soc., Vol. XXVIII, p. $107,1908$.

8. Querenghi, Fr._-" Microptalmo Congenito con stafiloma posteriore progressivo." Annali di Ottalm., Vol. XVI, p. 190, 1887. (Nagel's Jahresb., 1887).

9. Posey, William C.- " Report of two unusual forms of congenital cataracts," Ophthalmic Record, p. 150, Vol. XIX, 1910.

10. Schultze, O. - "Ueber Albinismus und Mikrophthalmie." Phys. - med. Gesellsch. zu Würzburg. Ref. Münchener med. Wochenschr., p. 2445, 1505.

11. Best, F.- "Korectopie." Arch.f. Ophthal., Vol. XL, Part iv, p. 198. Leipzig, 1894.

\section{A LETTER FROM BENJAMIN GIBSON OF MAN- CHESTER ON THE SUBJECT OF THE PUBLICATION OF HIS BOOK}

BY

R. R. JAMES

LONDON.

THE following letter, which has recently come into my hands, may be of interest to readers of the BRITISH JOURNAL OF Ophthalmology. Addressed to Messrs. Cadell \& Davies, Booksellers, London, it runs as follows :-

Manchester, October 22, 1810.

GentLEMEN,

By the recommendation of my friend Dr. Ferriar, I address you, 